Original research article

\title{
Incidence of ventilator-associated pneumonia at ICU - the effect of preventive measures in nursing care
}

\author{
Dimitris Jatagandzidis ${ }^{1}$, Markéta Kočí ${ }^{1,2}$, Renáta Zoubková ${ }^{1,2}$ * \\ ${ }^{1}$ University Hospital in Ostrava, Clinic of Anesthesiology/Critical Care, Ostrava, Czech Republic \\ ${ }^{2}$ University of Ostrava, Faculty of Medicine, Ostrava, Czech Republic
}

\section{Abstract}

Introduction: Pneumonia in patients on mechanical ventilation is the most frequently observed infectious complication in intensive care patients. The primary objective of the presented work was to evaluate compliance with procedures intended for the prevention of ventilator-associated pneumonia (VAP) in clinical practice at the Intensive Care Unit, University Hospital Ostrava (ICU UHO). The secondary objectives were to evaluate the incidence of VAP and the effect of a checklist introduced for prevention of VAP.

Methods: The study group consisted of a total of 525 patients hospitalized at the ICU UHO between 2016 and 2017 . The research was performed with analysis of data obtained from the introduced checklist of VAP. In patients who were mechanically ventilated and not admitted to the hospital with a primary diagnosis of pneumonia or already confirmed VAP.

Results: In the overall assessment, compliance with only 2 of the 4 evaluated preventive measures against the onset of VAP was recorded in $58.10 \%$. At one of the observed ICU, the incidence of VAP decreased by more than $50 \%$ after the introduction of the checklist. The results confirmed a statistically significant difference in the relation between positioning the patient in a semirecumbent position, maintaining pressure in the obturation cuff of the endotracheal tube within the recommended range, and the need to reintubate and the incidence of VAP. No statistically significant difference was observed in the relation between the performance of subglottic suctioning and the incidence of VAP.

Conclusions: The results of the survey show that the implemented system of prevention and the newly elaborated checklist lead to a decreased incidence of VAP.
\end{abstract}

Keywords: Checklist; System of prevention; Ventilator-associated pneumonia

\section{Introduction}

Ventilator-associated pneumonia (VAP), which belongs among a specific group of nosocomial infections (HAP - hospital-acquired pneumonia), currently represents the second most frequently observed group of nosocomial infections. It is responsible for up to $25 \%$ of the total number of infections (Kolek et al., 2014). Ventilator-associated pneumonia occurs in $90 \%$ of patients on mechanical ventilation (MV). The period with the highest risk of the onset of VAP is the first five days, during which the risk of infection increases by up to $3 \%$ every day. On the contrary, in the case of MV lasting longer than five days, the risk of infection slightly decreases (Streitová and Zoubková, 2015).

Factors leading to the onset of ventilator-associated pneumonia may be divided into influenceable and non-influenceable. The factors, which may be influenced, include mainly the clinical staff that is responsible for complying with the preventive measures, especially respecting the barrier approach in patient treatment, management of nursing care and treatment strategy (Oliveira et al., 2014). The preventive measures generally play a pivotal role in the incidence of nosocomial infections. These measures have been incorporated into an anti-epidemic plan; however, other specific procedures must also be followed in the course of the nursing process (Davidson et al., 2016; Kalil et al., 2016).

The aim of the preventive measures is to eliminate possible causes of the onset of VAP. The greatest role in the pathogenesis of VAP is played by bacterial colonization of the oropharynx and the gastric mucosa, with subsequent translocation of the pathogens into the lower respiratory tract (Goel et al., 2016). The incidence of VAP is not associated with the ventilator as such, but with the presence of the endotracheal tube (ET) - which is considered the main risk factor for the onset of VAP (Lau et al., 2015). It causes an attenuation of natural protective mechanisms of the body, such as the cough reflex with mucociliary clearance, which two hours after intubation already decreases to less than one half of the original value. The tube makes direct communication between the oral (supraglottic) space and the lower respiratory tract possible. Due to insufficient sealing of the ET cuff, chronic microaspiration of oropharyngeal secretions accumulated above the ET cuff occurs (mainly the contents of oropharyngeal cavities, fron-

\footnotetext{
* Corresponding author: Renáta Zoubková, University Hospital in Ostrava, Clinic of Anesthesiology/Critical Care, 17. listopadu 1790, 70852 Ostrava, Czech Republic; e-mail: renata.zoubkova@fno.cz http://doi.org/10.32725/kont.2020.046 
tal sinuses, and the gastrointestinal tract), which are present in $88-100 \%$ of intubated patients, and it represents, together with a formation of biofilm, the two most important mechanisms in the development of VAP (Zolfaghari and Wyncoll, 2011). These secretions are accumulated in the subglottic space, and that is why they cannot be effectively removed with suctioning from the oral cavity. The volume of this space is approximately $10 \mathrm{ml}$; accumulation of large secretion volumes of up to 100-150 ml/day has been observed. The onset of microaspiration is enhanced, among other things, by the supine position of the patient and the presence of nasogastric tube in patients on MV. Microaspiration is also present during PEEP loss, when the circulation of the ventilator becomes disconnected, and with provocation of negative intrathoracic pressures during routine airway suctioning. The bacterial colonization of ET, which leads to formation of biofilm, is an aggregate of microorganisms, which stick together due to the formed "culture medium" consisting of polysaccharides, proteins, and DNA. Bacteria also easily adhere to the ET surface, where they multiply. All these processes occur very quickly, within several hours following endotracheal intubation (Mietto et al., 2013).

The primary objective of the presented work was to assess compliance with procedures intended for prevention of ventilator-associated pneumonia in clinical practice at the Clinic of Anaesthesia, Resuscitation and Intensive Care Medicine (CARIM) at the University Hospital Ostrava (CARIM UHO).

\section{Materials and methods}

The retrospective study was performed at CARIM UHO; a total of 525 inpatients hospitalized at inpatient wards between 2016 and 2017 were enrolled in the study. The inclusion criterion was MV exceeding the period of 48 hours. The exclusion criteria were a basic diagnosis of pneumonia and earlier diagnosed (outside CARIM) ventilator-associated pneumonia.

Information from the patients' medical records was used to analyse the data. The authors evaluated the record from the checklist for VAP prevention. This has been introduced into nursing care at CARIM UHO, and is being used for all patients who are mechanically ventilated for a period exceeding 48 hours, in order to implement the recommended measures according to the Guidelines for prevention of VAP into clinical practice (see Annex). The assessed nursing interventions were the semirecumbent position, subglottic suction, pressure in the obturation cuff, and reintubation was another monitored parameter. For all these preventive measures, their compliance / non-compliance and their final consequence related to the occurrence of VAP were determined. The hypotheses were tested using Pearson's test of independence. The statistical level of significance was set at $5 \%$. The retrospective study was approved by the FHO Ethics Committee, processed within the diploma thesis at the University of Ostrava.

\section{Results}

In the period between 2016 and 2017, a total of 31 patients were diagnosed with VAP. This primarily originated at inpatient wards of CARIM UHO and was confirmed with microbiological testing. In 2016, VAP was observed in $4.72 \%$ of patients (12 patients from the total number of 254 patients), and in 2017, the incidence was $7.01 \%$ (19 patients from the total number of 271 patients). The average number of patients affected by this nosocomial infection was $5.9 \%$. The VAP rate at CARIM UHO was 6.3 per 1,000 ventilator days in 2017 (Table 1).

Table 1. VAP incidence
\begin{tabular}{lcc} 
Year & $n$-absolute frequency & $n$-relative frequency (\%) \\
\hline 2016 & 12 & 4.72 \\
2017 & 19 & 7.01 \\
$2016-2017$ & 31 & 5.90 \\
\hline
\end{tabular}

In order to assess the effect of the introduced protocol (Checklist - VAP Prevention) for the realization of preventive measures in nursing care provided for patients at CARIM, the authors used retrospective data regarding the incidence of VAP between 2013 and 2016 at one of the inpatient wards of CARIM UHO. Between 2013 and 2015, the nursing staff performed preventive measures against the incidence of VAP without the VAP Prevention checklist. The VAP checklist (Annex) was introduced into practice on 1st July 2015. There were 10 cases of VAP at the Intensive Care Unit No 1 (ICU 1) ward in 2013, 10 cases in 2014, and 11 cases in 2015.

In 2016, VAP was diagnosed in 4 patients only. These findings show that the incidence of ventilator-associated pneumonia in 2016 was more than 50\% lower than the period of 2013-2015.

When assessing the effect of the introduced preventive measures upon the incidence of VAP, the authors monitored the compliance with three selected interventions - suctioning from the subglottic space, placement of the patient into the semirecumbent position, and maintaining the recommended pressure in the obturation cuff. As well as this, the parameter of reintubation in prematurely extubated patients was also monitored.

The relation between complying with the preventive measures and using the checklist for VAP prevention, and the incidence of ventilator-associated pneumonia was evaluated using the Pearson's test of independence. Furthermore, so-called residua exceeding the threshold value of 1.96 of the Gaussian quantile in cases of statistically significant deviations were also evaluated (Table 2).

The obtained results clearly show that observing preventive measures in patients on MV has an effect on the onset of ventilator-associated pneumonia. From the results given in Table 3, the statistical significance is $p<0.05$. It is stated that preventive measures in patients with UPV have an effect on the development of ventilator-associated pneumonia. Furthermore, it can be seen from the residues that there are significantly more patients who developed VAP due to none or only one of the four preventive measures $(p=7.47)$. The incidence of VAP in the evaluation of implementation of 2 preventive measures (semirecumbent position and subglottic aspiration) was significantly lower $(p=0.000)$. From the results (Table 3 ), it is clear that VAP was observed in patients in whom only one of the three selected preventive measures was applied, or in whom reintubation was required. A statistically significant difference was observed when comparing maintaining the recommended pressure in the obturation cuff and the incidence of diagnosed VAP $(p=0.000)$. At the same time, a dependency was confirmed between maintaining the semirecumbent position of the patient on MV and the onset of VAP. A statistically significant difference was also confirmed when evaluating the relation between the need to perform reintubation in extubated patients and the onset of ventilator-associated pneumonia $(p=0.000)$. 
Table 2. Compliance with preventive measures and reintubation

\begin{tabular}{|c|c|c|c|c|c|c|}
\hline \multirow{2}{*}{$\begin{array}{l}\text { Year } \\
\text { Compliance } \\
\text { with preventive } \\
\text { measures }\end{array}$} & \multicolumn{2}{|c|}{2016} & \multicolumn{2}{|c|}{2017} & \multicolumn{2}{|c|}{ 2016-2017 } \\
\hline & $\begin{array}{l}n \text {-absolute } \\
\text { frequency }\end{array}$ & $\begin{array}{c}n \text { - relative } \\
\text { frequency } \\
(\%)\end{array}$ & $\begin{array}{l}n-\text { absolute } \\
\text { frequency }\end{array}$ & $\begin{array}{c}n \text { - relative } \\
\text { frequency } \\
(\%)\end{array}$ & $\begin{array}{l}n \text {-absolute } \\
\text { frequency }\end{array}$ & $\begin{array}{c}n \text { - relative } \\
\text { frequency } \\
(\%)\end{array}$ \\
\hline 0 - none & 1 & 0.39 & 2 & 0.74 & 3 & 0.57 \\
\hline 1 & 3 & 1.18 & 6 & 2.21 & 9 & 1.71 \\
\hline 2 & 156 & 61.42 & 149 & 54.98 & 305 & 58.10 \\
\hline 3 & 93 & 36.61 & 111 & 40.96 & 204 & 38.86 \\
\hline 4 - all & 1 & 0.39 & 3 & 1.11 & 4 & 0.76 \\
\hline
\end{tabular}

Table 3. Prevention and residua in relation to VAP incidence

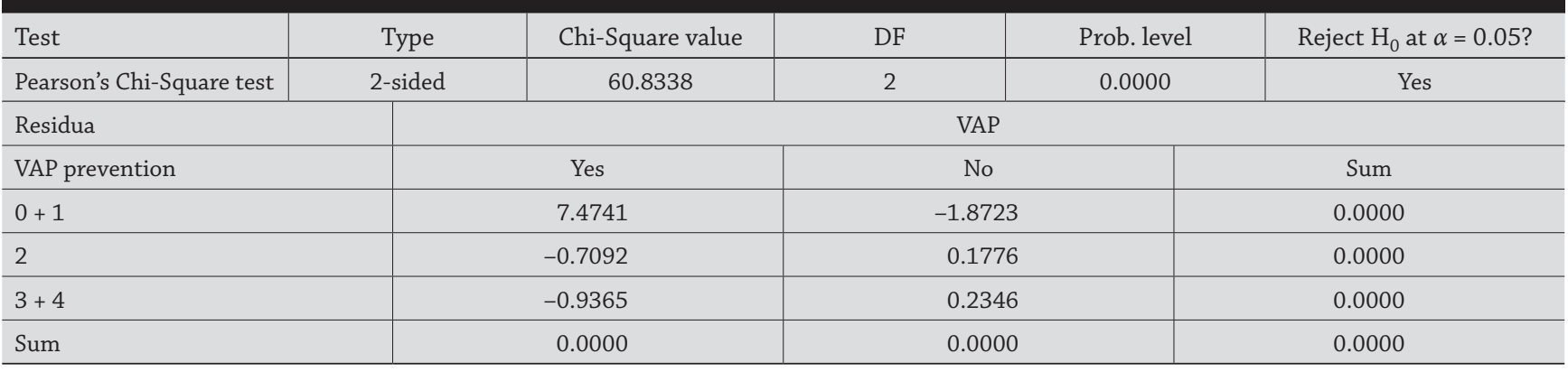

\section{Discussion}

Based upon the results of the study, it is possible to conclude that the performance of the introduced preventive measures significantly influences the incidence of ventilator-associated pneumonia. It was confirmed that non-performance of any or performance of only one of the three preventive measures, or the need of reintubation, have a significant impact upon the increased number of patients diagnosed with VAP. The effect of compliance with the complex set of strategic procedures with a demonstrated effect upon a significant decrease of VAP incidence has a great impact upon decreasing the incidence of this disease, as has been confirmed with numerous studies performed at departments of intensive care (Álvarez-Lerma et al., 2014; Oliveira et al., 2014). As an example, it is possible to mention the study performed by Hungarian authors, which showed a decreased incidence of VAP and decreased relative risk of $44 \%$ following the introduction of the preventive bundle of measures (Mogyoródi et al., 2016).

The basic and simplest measure in VAP prevention is keeping the patient in a semirecumbent position, which has a positive effect upon decreasing the incidence of VAP (Caserta et al., 2012; Dosher et al., 2014; El Azab et al., 2013). Data from our study show that this simple intervention was applied in $96.57 \%$ of cases. The patients in whom this intervention was not applied were patients with polytrauma; predominantly with pelvic and spinal injuries. The semirecumbent position was contraindicated in these patients. According to the results of Dostál (2015), the semirecumbent position was applied in patients at CARIM department of the Military Hospital Prague in $75-80 \%$ of cases in 2013. Taking into consideration the fact that the department provides intensive care, it is not always possible to ensure continuity of this patient position due to the need to transport the patient for various examinations, and the diagnostic-treatment interventions performed at the patient's bedside (Dostál, 2015). Accordingly, it was concluded that in patients lying in a supine position, with attenuated reflexes and protective mechanisms, the risk of gastroesophageal reflux is greater, with subsequent microaspiration of the gastric content. (Sedwick et al., 2012) Also, a systematic review of authors from China showed that the semirecumbent position of $30^{\circ}$ to $60^{\circ}$ may effectively decrease the clinically suspected VAP when compared with the supine position of $0^{\circ}$ to $10^{\circ}$ (Wang et al., 2016).

Another measure preventing aspiration is maintaining optimal pressure in the obturation cuff of the endotracheal tube. In the study population, the authors confirmed the relation between maintaining optimal pressure in the obturation cuff and the onset of VAP, and have concluded that not maintaining an optimal pressure in the recommended range significantly influences VAP incidence (Blot et al., 2014; Coppadoro et al., 2012; Guanche-Garcell et al., 2013; Lau et al., 2015; Lorente et al., 2007; Zolfaghari and Wyncoll, 2011). An identical observation was made in a clinical trial from 2017, which, among other things, evaluated the incidence of ventilator-associated pneumonia in two different ranges of pressure in the obturation cuff. The first group consisted of study subjects with pressures of $22-23 \mathrm{cmH}_{2} \mathrm{O}$, and pressures of $15-30 \mathrm{cmH}_{2} \mathrm{O}$ were applied in the second group. No statistically significant difference in the prevention of the onset of VAP was observed between these two groups (Bulamba et al., 2017). These findings have been confirmed by the results of yet another study. In the conclusion, the authors claim that obturation pressure lower 
than $20 \mathrm{cmH}_{2} \mathrm{O}$ increases the incidence of VAP from $11.2 \%$ to 22.0\% (Lorente et al., 2014).

Furthermore, we also monitored the relation between the VAP incidence, depending on the possibility of subglottic suctioning in airways secured with endotracheal tube or tracheostomy. In 2016, a total of 101 patients (39.76\%) had endotracheal tube with the possibility of subglottic suctioning inserted. In 2017, subglottic suctioning was performed in $44.65 \%$ (121 patients). Subglottic suctioning is included in the VAP checklist used at the CARIM department, and is one of the parameters evaluated by the nursing staff; the Pearson's test of independence ( $p>0.05)$ confirmed that suctioning from the subglottic space does not influence the onset of ventilator-associated pneumonia in any way. This conclusion is contrary to the conclusions of a number of other clinical trials, which recommend subglottic suctioning as one of the important preventive measures (Frost et al., 2013; Lorente et al., 2014; Wang et al., 2015; Xie et al., 2012). A total of thirteen randomized clinical trials performed at Queen's University in Ontario, Canada, enrolled a total of 2,442 patients with the possibility of approaching the subglottic space. The authors observed postponing of the first VAP episode from 2.66 days by 1.06-4.26 days, and a decreased length of hospitalization by 1.52-2.94 days (Muscedere et al., 2011). Also, a study performed by French authors (between 2013 and 2016) which enrolled 333 patients, confirmed that removal of secretions from the subglottic space during MV leads to a significant decrease of VAP, including the VAP with a late onset (Lacherade et al., 2010). The last evaluated intervention was planned or unplanned reintubation. In 2016, reintubation was performed in $3.15 \%$, and in 2017 in $2.95 \%$ of patients.

Based upon the acquired data, it is possible to confirm the statistically significant relation between reintubation and the secondarily introduced tracheostomy cannula, and the higher incidence of VAP. This observation was also confirmed by a clinical trial performed in 2016. (Gosseling et al., 2007) The study of Dostál (2015) concluded that unplanned reintubation of patients serves as an independent risk factor for VAP onset. Another consequence of unplanned reintubation, as has been reported in literature, is the increasing patient mortality by 25-50\% (Gadani et al., 2010).

The retrospective study performed at CARIM UHO (between 2016 and 2017) recorded 31 patients diagnosed with VAP confirmed with microbiological tests, and this primarily originated at CARIM UHO. A total of $4.72 \%$ of patients with VAP were diagnosed in 2016, and $7.01 \%$ in 2017 . The average percentage of patients affected with this nosocomial infection was $5.9 \%$. According to the study performed by Kalanuria et al. (2014), the range incidence of VAP, which originated at ICU varies between 1.2 and 8.5 per 1,000 ventilator days (Kalanuria et al., 2014). The "Pneumonia Zero" study, which was performed at 181 intensive care units in Spain - with a total number of 171,237 enrolled study subjects - observed a decrease in the incidence of VAP up to the final 4.34 per 1,000 ventilator days after the introduction of the bundle of preventive measures (Álvarez-Lerma et al., 2018). One of the reasons for the increased incidence of VAP in 2017 by $2.29 \%$ is the adjustment and unification of criteria for the evaluation of ventilator-associated pneumonia at the beginning of 2017. Another reason is the personal shortage of nurses in the course of 2017. This factor correlates with the data from the study of Valencia et al. (2007), which showed that one of the possible reasons for performing the preventive measures only partially may be smaller numbers of nursing personnel. This retrospective study dealing with the ratio of nurses to the number of patients in intensive care concluded that a higher number of nurses on a shift leads to a significant decrease in the risk of nosocomial infections (Valencia et al., 2007).

As has already been mentioned, the effect of the introduced checklist 'VAP Prevention' was evaluated with the analysis of data from one inpatient ward at CARIM UHO. The authors retrospectively compared the VAP incidence before and after the introduction of the VAP Prevention checklist. Between 2013 and 2015, the preventive measures against VAP were performed without any records in the VAP Prevention checklist. Since mid-2015, when the protocol (VAP checklist) was introduced into practice, the incidence of ventilator-associated pneumonia decreased by $50 \%$ when compared with the previous years. There were 11 cases of VAP diagnosed at the observed inpatient ward in 2015, and only 4 cases in the following year.

\section{Conclusions}

Based upon the analysis of the obtained data, it is possible to conclude that the incidence of ventilator-associated pneumonia at CARIM ICU varies within ranges comparable to other countries. The preventive bundles, together with the VAP checklist, play an important role in decreasing the incidence of this complication. The individual nursing and preventive measures have a positive effect on the incidence of VAP. The VAP prevention checklist can significantly help to implement nursing interventions in VAP prevention. Thus, the incidence of VAP decreases every year, due to the more effective compliance with preventive measures. Performance of these measures currently belongs among the basic care provided for patients on mechanical ventilation, which results in a higher quality of the complex care provided for critically ill patients.

\section{Conflict of interests}

The authors have no conflict of interests to declare.

\section{Author contributions}

D.J., M.K. designed the study, collected the data, conducted the statistical analysis, and drafted the manuscript; R.Z. designed the study and wrote and finalized the manuscript. 


\section{Výskyt ventilátorové pneumonie v intenzivní péči - efekt preventivních ošetřovatelských intervencí}

\section{Souhrn}

Úvod: Pneumonie je u pacientů s umělou plicní ventilací nejčastější pozorovanou infekční komplikací na jednotce intenzivní péče. Cílem práce bylo zhodnotit dodržování postupů pro prevenci ventilátorové pneumonie v klinické praxi na Klinice anestezie, resuscitace a intenzivní medicíny ve Fakultní nemocnici Ostrava (KARIM FNO). Dílčí cíle byly zaměřeny na zhodnocení výskytu ventilátorové pneumonie a posouzení efektu zavedeného checklistu pro prevenci ventilátorové pneumonie v klinické praxi. Metodika: Výzkumný soubor tvořilo 525 hospitalizovaných pacientů v letech 2016 a 2017 na KARIM FNO. Výzkum byl realizován analýzou dat ze zavedeného checklistu ventilátorové pneumonie u pacientů, kteří byli napojeni na umělou plicní ventilaci, nebyli přijati již s primárně diagnostikovanou pneumonií nebo již prokázanou ventilátorovou pneumonií.

Výsledky: Dle celkového hodnocení bylo nejčetněji zaznamenáno dodržování pouze dvou ze čtyř hodnocených preventivních opatření pro vznik ventilátorové pneumonie, a to v 58,10 \%. Na jednotce intenzivní péče došlo ke snížení výskytu ventilátorové pneumonie o více než $50 \%$ po zavedení checklistu. Byl potvrzen statisticky významný vliv na snížení výskytu ventilátorové pneumonie při udržování pacienta v semirekumbentní poloze, udržení tlaku v obturační manžetě endotracheální kanyly v doporučeném rozmezí a nižšího podílu reintubace. Naopak nebyl potvrzen statisticky významný rozdíl ve vztahu mezi prováděním subglotického odsávání k výskytu ventilátorové pneumonie.

Závěr: Z výsledků šetření bylo zjištěno, že nastavený systém prevence a vytvořený checklist vede ke snížení výskytu ventilátorové pneumonie.

Klíčová slova: check-list; systém prevence; ventilátorová pneumonie

\section{References}

1. Álvarez-Lerma F, Palomar-Martínez M, Sachez-García M, Matínez-Alonso M, Álvarez-Rodríguez J, Lorente L, et al. (2018). Prevention of Ventilator-Associated Pneumonia: The Multimodal Approach of the Spanish ICU "Pneumonia Zero" Program. Crit Care Med 46(2): 181-188. DOI: 10.1097/ CCM.0000000000002736.

2. Álvarez-Lerma F, Sánchez-García M, Lorente L, Gordo F, Añón JM, Älvarez J, et al. (2014). Guidelines for the prevention of ventilator-associated pneumonia and their implementation. The Spanish “Zero-VAP” bundle. Med Intensiva 38(4): 226-236. DOI: 10.1016/j.medin.2013.12.007.

3. Blot SI, Poelaert J, Kollef M (2014). How to avoid microaspiration? A key element for the prevention of ventilator associated pneumonia in intubated ICU patients. BMC Infect Dis 14(1): 1-6. DOI: 10.1186/1471-2334-14-119.

4. Bulamba F, Kintu A, Ayupo N, Kojjo Ch, Ssemogerere L, Wabule A, et al. (2017). Achieving the Recommended Endotracheal Tube Cuff Pressure: A Randomized Control Study Comparing Loss of Resistance Syringe to Pilot Balloon Palpation. Anesthesiol Res Pract 2017: 2032748. DOI: 10.1155/2017/2032748.

5. Caserta RA, Marra AR, Durao MS, Silva CV, Pavao dos Santos PV, Suton de Sonta Neves H, et al. (2012). A program for sustained improvement in preventing ventilator associated pneumonia in an intensive care setting. BMC Infect Dis 12(234): 2-8. DOI: 10.1186/1471-2334-12-234.

6. Coppadoro A, Bittner E, Berra L (2012). Novel preventive strategies for ventilator-associated pneumonia. Crit Care 16(2): 2-6. DOI: 10.1186/cc11225.

7. Davidson C, Banham S, Elliott M, Kennedy D, Gelder C, Glossop A (2016). British Thoracic Society/Intensive Care Society Guideline for the ventilatory management of acute hypercapnic respiratory failure in adults. BMJ Open Respir Res 3(1). DOI: 10.1136/bmjresp-2016-000133.

8. Dosher WB, Loomis EC, Richardson SL, Crowell JA, Waltman RD, Miller LD, et al. (2014). The Effect of a NurseLed Multidisciplinary Team on Ventilator-Associated Pneumonia Rates. Crit Care Res Pract 682621, 5 p. DOI: $10.1155 / 2014 / 682621$.
9. Dostál P (2015). Nozokomiální pneumonie ventilovaných nemocných - je skutečně nevyhnutelnou komplikací umělé plicní ventilace? Anest Itenziv Med 26(6): 317-318.

10. El Azab SR, El Sayed AE, Abdelkarim M, Al Mutairi KB, Al Saqabi A, El Demerdash S (2013). Combination of ventilator care bundle and regular oral care with chlorhexidine was associated with reduction in ventilator associated pneumonia. Egypt J Anaesth 29(3): 273-277. DOI: 10.1016/j. egja.2013.03.001.

11. Frost SA, Azeem A, Alexandrou E, Tam V, Murphy JK, Hunt L, et al. (2013). Subglottic secretion drainage for preventing ventilator-associated pneumonia: A meta-analysis. Aust Crit Care 26(4): 180-188. DOI: 10.1016/j. aucc.2013.03.003.

12. Gadani H, Vyas A, Kar AK (2010). A study of ventilatorassociated pneumonia: Incidence, outcome, risk factors and measures to be taken for prevention. Indian J Anaesth 54(6): 535-540. DOI: 10.4103/0019-5049.72643.

13. Goel V, Gupta S, Goel T (2016). Ventilator-associated pneumonia: A review of the clinically relevant challenges in diagnosis and prevention. BJMP 9(2): 910-918.

14. Gosseling R, Bott J, Johnson M, Dean E, Nava S, Norrenberg M, et al. (2007). Physiotherapy for adult patients with critical illness: recommendations of the European Respiratory Society and European Society of Intensive Care Medicine Task Force on Physiotherapy for Critically Ill Patients. Intensive Care Med 34(7): 1188-1199. DOI: 10.1007/s00134-008-1026-7.

15. Guanche-Garcell H, Morales-Perez C, Rosenthal VD (2013). Effectiveness of a multidimensional approach for the prevention of ventilator-associated pneumonia in an adult intensive care unit in Cuba: Findings of the International Nosocomial Infection Control Consortium (INICC). J Infect Public Health 6(2): 98-107. DOI: 10.1016/j.jiph.2012.11.009.

16. Kalanuria A, Zai W, Mirski M (2014). Ventilator-associated pneumonia in the ICU. Crit Care 18(2): 208. DOI: 10.1186/ cc13775.

17. Kalil AC, Metersky ML, Klompas M, Muscedere J, Sweeney DA, Palmer LB, et al. (2016). Management of Adults With Hospitalacquired and Ventilator-associated Pneumonia: 2016 Clinical Practice Guidelines by the Infectious Diseases Society of America and the American Thoracic Society. Clin Infect Dis 63(5): 61-111. DOI: 10.1093/cid/ciw353. 
18. Kolek V, Kašák V, Vašáková M (2014). Pneumologie. 2nd extended ed. Prague: Maxdorf. 645 p.

19. Lacherade J, De Jonghe B, Guezennec P, Debbat K, Hayon J, Monset A, et al. (2010). Intermittent Subglottic Secretion Drainage and Ventilator-associated Pneumonia: A Multicenter Trial. Am J Respir Crit Care Med 182(7): 910-917. DOI: 10.1164/rccm.200906-08380C.

20. Lau ACW, So HM, Tang SL, Yeung A, Lam SM, Yan WW, et al. (2015). Prevention of ventilator-associated pneumonia. Hong Kong Med J 21(1): 61-68. DOI: 10.12809/hkmj144367.

21. Lorente L, Lecuona M, Jiménez A, Lorenzo L, Roca I, Cabrera J, et al. (2014). Continuous endotracheal tube cuff pressure control system protects against ventilatorassociated pneumonia. Crit Care 18(2): R77. DOI: 10.1186/ cc13837.

22. Lorente L, Lecuona M, Jimenéz A, Mora ML, Sierra A (2007). Influence of an endotracheal tube with polyurethane cuff and subglottic secretion drainage on pneumonia. Am J Respir Crit Care Med 176(11): 1079-1083. DOI: 10.1164/rccm.200705761OC.

23. Mietto C, Pinciroli R, Patel N, Berra L (2013). Ventilator Associated Pneumonia: Evolving Definitions and Preventive Strategies Discussion. Respir Care 58(6): 990-1007. DOI: $10.4187 /$ respcare.02380.

24. Mogyoródi B, Dunai E, Gál J, Zsolt I (2016). Ventilatorassociated pneumonia and the importance of education of ICU nurses on prevention - Preliminary results. Interv Med Appl Sci 8(4): 147-151. DOI: 10.1556/1646.8.2016.4.9.

25. Muscedere J, Rewa O, McKechnie K, Jiang X, Laporta D, Heylang DK (2011). Subglottic secretion drainage for the prevention of ventilator-associated pneumonia: A systematic review and meta-analysis. Crit Care Med 39(8): 1985-1981. DOI: 10.1097/CCM.0b013e318218a4d9.
26. Oliveira J, Zagalo C, Cavaco-Silva P (2014). Prevention of ventilator-associated pneumonia. Rev Port Pneumol 20(3): 152-161.

27. Sedwick MB, Lance-Smith M, Reeder SJ, Nardi J (2012). Using evidence-based practice to prevent ventilator-associated pneumonia. Crit Care Nurse 32(4): 41-51. DOI: 10.4037/ ccn2012964.

28. Streitová D, Zoubková R (2015). Septické stavy v intenzivní péči: Ošetřovatelská péče. Prague: Grada Publishing.185 p.

29. Valencia M, Ferrer M, Farre R, Navajas D, Badia JR, Nicolas JM, et al. (2007). Automatic control of tracheal tube cuff pressure in ventilated patients in semirecumbent position: a randomized trial. Crit Care Med 35(6): 1543-9. DOI: 10.1097/01. CCM.0000266686.95843.7D.

30. Wang L, Li X, Yang Z, Tang X, Yuan Q, Deng L, Sun X (2016). Semi-recumbent position versus supine position for the prevention of ventilator-associated pneumonia in adults requiring mechanical ventilation. Cochrane Database Syst Rev 2016(1): CD009946. DOI: 10.1002/14651858.CD009946.

31. Wang R, Zhen X, Yang B, Guo X-Z, Zeng X, Deng C-Y (2015). Subglottic secretion drainage for preventing ventilatorassociated pneumonia: A meta-analysis. Chin Nurs Res 2: 55-60. DOI: 10.1016/j.cnre.2015.03.001.

32. Xie X, Nicolau I, McGregor M, Dendukuri N (2012). Subglottic Secretion Drainage Endotracheal Tubes for Prevention of Ventilator-Associated Pneumonia. Montreal (Canada): Technology Assessment Unit (TAU) of the McGill University Health Centre (MUHC). [online] [cit. 2020-01-22]. Available from: https://muhc.ca/sites/default/files/micro/m-TAU/muhc tau_2011_56_ssd.pdf

33. Zolfaghari PS, Wyncoll DLA (2011). The tracheal tube: gateway to ventilator-associated pneumonia. Crit Care 15(5): 1-8. DOI: $10.1186 /$ cc10352. 